\title{
Three New Isoprenylated Flavonoids from the Root Bark of Morus alba
}

\author{
Jae-Woo Jung ${ }^{1}$, Ji-Hae Park ${ }^{1}$, Yeong-Geun Lee ${ }^{1}$, Kyeong-Hwa Seo ${ }^{2}$, Eun-Ji Oh ${ }^{1}$, \\ Dae-Young Lee ${ }^{3}$, Dong-Wook Lim ${ }^{4}$, Daeseok Han ${ }^{4}$ and Nam-In Baek ${ }^{1, *}$ \\ 1 Graduate School of Biotechnology and Oriental Medicine Biotechnology, Kyung Hee University, \\ Yongin 17104, Korea; jaewoo4848@naver.com (J.-W.J.); pjh3411@kbsi.re.kr (J.-H.P.); \\ lyg629@nate.com (Y.-G.L.); JK3172@nate.com (E.-J.O.) \\ 2 Natural Medicine Research Center, KRIBB, Chengju 28116, Korea; khseo@kribb.re.kr \\ 3 Department of Herbal Crop Research, National Institute of Horticultural and Herbal Science, RDA, \\ Eumseong 27709, Korea; dylee0809@korea.kr \\ 4 Division of Metabolism and Functionality Research, Korea Food Research Institute, Sungnam 463-746, \\ Korea; neodw4015@kfri.re.kr (D.-W.L.); imissu@kfri.re.kr (D.H.) \\ * Correspondence: nibaek@khu.ac.kr; Tel.: +82-31-201-2661; Fax: +82-31-204-8116 \\ Academic Editors: Arturo San Feliciano and Celestino Santos-Buelga \\ Received: 12 July 2016; Accepted: 19 August 2016; Published: 24 August 2016
}

\begin{abstract}
Phytochemical investigation of the root bark of Morus alba has led to the isolation and identification of three new isoprenylated flavonoids, namely sanggenon $U(\mathbf{1})$, sanggenon $V(\mathbf{2})$, and sanggenon W (3), along with four known isoprenylated flavonoids: euchrenone $a_{7}(4)$, sanggenon J (5), kuwanon E (6), and kuwanon $\mathrm{S}$ (7). All compounds were isolated by repeated silica gel $\left(\mathrm{SiO}_{2}\right)$, octadecyl $\mathrm{SiO}_{2}$ (ODS), and Sephadex LH-20 open column chromatography. The structure of the compounds were determined based on spectroscopic analyses, including nuclear magnetic resonance (NMR), mass spectrometry (MS), circular dichroism (CD), and infrared (IR). In addition, compounds 1-4 were isolated for the first time from the root bark of $M$. alba in this study.
\end{abstract}

Keywords: isoprenylated flavonoids; Morus alba; root bark; sanggenon U; sanggenon V; sanggenon W

\section{Introduction}

An isoprenylated flavonoid is formed by attachment of various prenyl moieties to a flavanone, flavone, flavanonol, flavonol, isoflavone, or chalcone. Barron et al. [1] proposed more than 600 structurally diverse prenylated flavonoids. Prenylated flavonoids are hybrid products composed of a flavonoid core usually attached to either 5-carbon or 10-carbon prenyl moieties derived from isoprenoid metabolism. Prenylated flavonoids are widely distributed in the Leguminosae, Moraceae, Euphorbiaceae, Guttiferae, and Umbelliferae plant families [1] and exhibit a variety of biological activities including anticancer [2,3] and the regulation of blood pressure via inhibition of NO production [4]. Especially, the addition of an isoprenoid moiety confers higher activity to the prenylated flavonoid molecule than in the parent flavonoid compound from the pharmacological point of view [5]. The proposed reason for the enhanced biological activity of prenylated flavonoid is that the attachment of the prenyl moiety to the flavonoid core increases the lipophilicity and the membrane permeability of the compound. In previous reports, several isoprenylated flavonoids, sanggenols, sanggenons, and kuwanons, were isolated from Morus alba L. in the family of Moraceae [6].

The mulberry tree (Morus alba L., Moraceae) is native to Thailand, and is widely cultivated in China, Korea, and Japan. Mulberry leaves, as the indispensable food of silkworms, are economically important sources for sericulture in East Asia [7]. Most parts of this tree has been widely used for a variety of medicinal purposes. The root bark, named "Sang-Bai-Pi", has been used for treating diabetics, relieving asthma, and protecting the liver [8]. Previously reported mulberry 
root bark compounds include isoprenylated flavonoids, Diels-Alder type adducts, triterpenoids, coumarins, benzofurans, and stilbenes [9-13]. These compounds are reported to show anti-oxidant, anti-inflammatory, anti-hepatitis B virus, anti-cancer, and anti-microbial activities [14-17]. The EtOAc soluble fractions of mulberry root bark recently revealed antidepressant effects in vivo [18] as well as isolation of a new hydroxyl fatty acid [19]. Therefore, isolation of active compounds from the root bark of $M$. alba was carried out. This paper describes the procedure for the isolation of three new and four known isoprenylated flavonoids through solvent extraction, solvent fractionation, and open column chromatography as well the identification of the chemical structure of the compounds on the basis of spectroscopic analyses such as NMR, IR, and MS experiments.

\section{Results and Discussion}

Repeated open column chromatography $\left(\mathrm{SiO}_{2}, \mathrm{ODS}\right.$, and Sephadex LH-20 resins) of the EtOAc fraction from the $M$. alba root bark resulted in the isolation of seven isoprenylated flavonoids, including three new compounds, named sanggenon U (1), sanggenon V (2), and sanggenon W (3), and four known compounds (4-7, Figure 1). The chemical structures of the isolated isoprenylated flavonoids were determined based on the analyses of $1 \mathrm{D}-\mathrm{NMR}\left({ }^{1} \mathrm{H}\right.$ and $\left.{ }^{13} \mathrm{C}\right)$ and 2D-NMR (DEPT, HSQC, HMBC, and COSY), MS, CD, and IR spectroscopic data. The known compounds were finally identified to be euchrenone $a_{7}(4)$, sanggenon $J(5)$, kuwanon $E(6)$, and kuwanon $S$ (7) by comparison of the spectroscopic data with those previously reported in the literature [20-23]. ${ }^{1} \mathrm{H}-\mathrm{NMR}$, and ${ }^{13} \mathrm{C}-\mathrm{NMR}$ spectra of three new compounds 1, 2 and 3 are available on the Supplementary Materials.

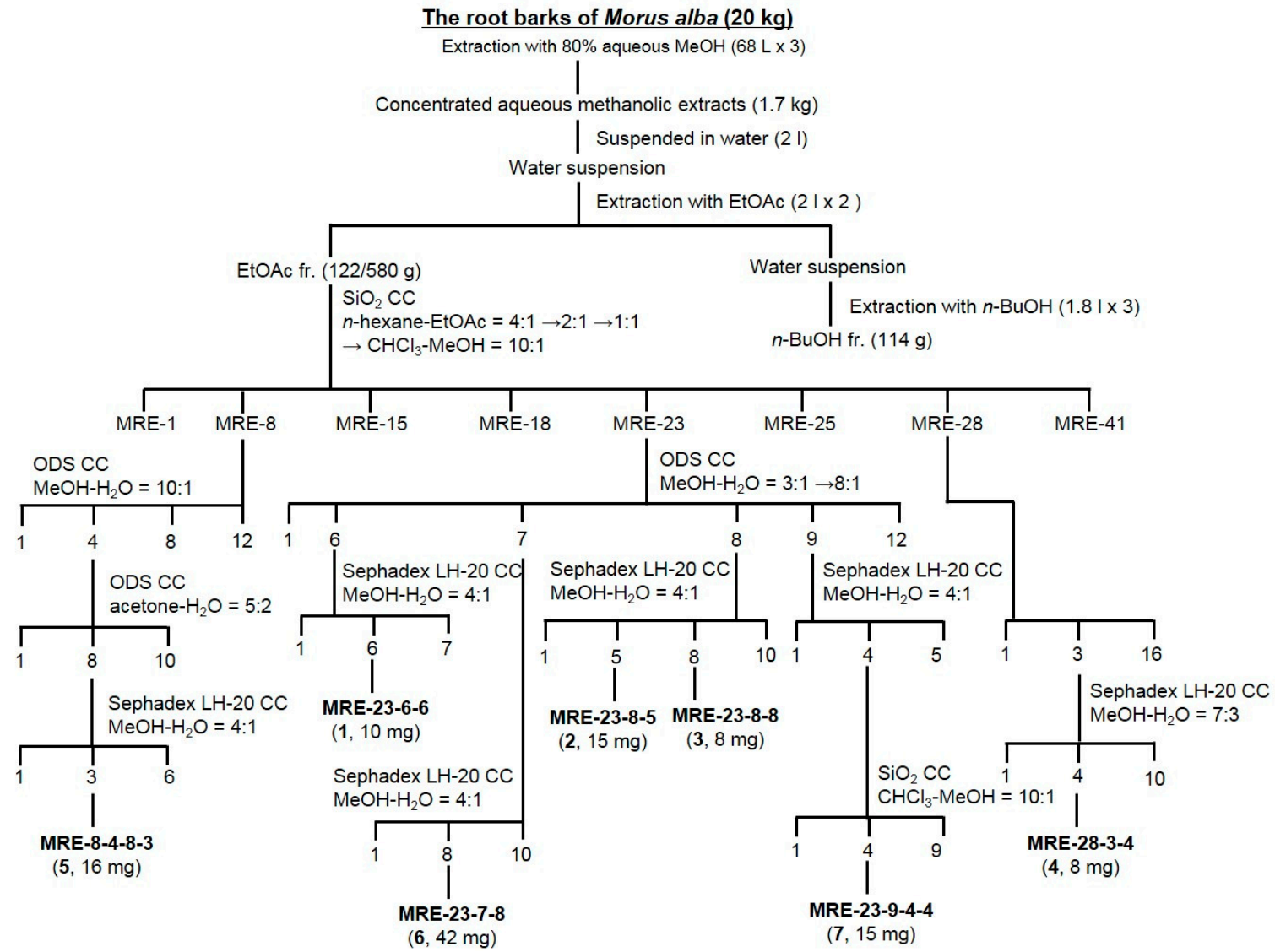

Figure 1. Extraction, fractionation, and isolation scheme of isoprenylated flavonoids from the root bark of Morus alba. $\mathrm{SiO}_{2}$ : silica gel; CC: column chromatography; ODS: octadecyl silica gel; MRE: EtOAc fraction of Morus alba root bark. 
Compound 1 was isolated as a yellow amorphous powder and showed characteristic UV absorptions at 254 and $365 \mathrm{~nm}$ and also a yellow color on the TLC plate when sprayed with $10 \%$ sulfuric acid and heating. The molecular weight was determined to be 510 from the molecular ion peak $m / z 510[\mathrm{M}]^{+}$in the EI/MS spectrum, and a molecular formula of $\mathrm{C}_{30} \mathrm{H}_{38} \mathrm{O}_{7}$ according to the high-resolved molecular ion peak $m / z 510.2616[\mathrm{M}]^{+}$(calcd for $\mathrm{C}_{30} \mathrm{H}_{38} \mathrm{O}_{7}, 510.2618$,) in the HR/EI/MS IR absorbance bands of hydroxyl $\left(3373 \mathrm{~cm}^{-1}\right)$, carbonyl $\left(1662 \mathrm{~cm}^{-1}\right)$, and aromatic $\left(1608,1577 \mathrm{~cm}^{-1}\right)$ groups were observed. In the ${ }^{1} \mathrm{H}-\mathrm{NMR}$ spectrum, one aromatic signal at $\delta_{\mathrm{H}} 7.03\left(1 \mathrm{H}, \mathrm{s}, \mathrm{H}-6^{\prime}\right)$ owing to a pentasubstituted benzene ring $B$ and two aromatic signals at $\delta_{\mathrm{H}} 5.90(1 \mathrm{H}, \mathrm{d}, J=2.0 \mathrm{~Hz}, \mathrm{H}-6)$ and 5.86 $(1 \mathrm{H}, \mathrm{d}, J=2.0 \mathrm{~Hz}, \mathrm{H}-8)$ due to a 1,2,3,5-tetrasubstituted benzene ring A were observed. In addition, the oxygenated methine signal at $\delta_{\mathrm{H}} 5.64(1 \mathrm{H}, \mathrm{dd}, J=12.8,2.8 \mathrm{~Hz}, \mathrm{H}-2)$, the methylene signals at $\delta_{\mathrm{H}} 3.08(1 \mathrm{H}, \mathrm{dd}, J=17.2,12.8 \mathrm{~Hz}, \mathrm{H}-3 \mathrm{a})$ and $2.69(1 \mathrm{H}, \mathrm{dd}, J=17.2,2.8 \mathrm{~Hz}, \mathrm{H}-3 \mathrm{~b})$ indicated the AMX system typical of a flavanone ring $\mathrm{C}$. The geranyl moiety proton signals such as two olefinic methines at $\delta_{\mathrm{H}} 5.18\left(1 \mathrm{H}, \mathrm{t}, J=6.8 \mathrm{~Hz}, \mathrm{H}-2^{\prime \prime}\right)$ and $5.06\left(1 \mathrm{H}, \mathrm{t}, J=6.8 \mathrm{~Hz}, \mathrm{H}-2^{\prime \prime \prime}\right)$, three methylenes at $\delta_{\mathrm{H}} 3.41$ $\left(2 \mathrm{H}, \mathrm{d}, J=6.8 \mathrm{~Hz}, \mathrm{H}-1^{\prime \prime}\right), 2.06\left(2 \mathrm{H}, \mathrm{dt}, J=6.8,6.8 \mathrm{~Hz}, \mathrm{H}-1^{\prime \prime \prime}\right)$, and $1.98\left(2 \mathrm{H}, \mathrm{d}, J=6.8 \mathrm{~Hz}, \mathrm{H}-5^{\prime \prime}\right)$, and three methyls at $\delta_{\mathrm{H}} 1.78\left(3 \mathrm{H}, \mathrm{s}, \mathrm{H}-4^{\prime \prime}\right), 1.62\left(3 \mathrm{H}, \mathrm{s}, \mathrm{H}-4^{\prime \prime \prime}\right)$, and $1.56\left(3 \mathrm{H}, \mathrm{s}, \mathrm{H}-5^{\prime \prime \prime}\right)$ were observed. Moreover, two methylenes at $\delta_{\mathrm{H}} 2.63\left(2 \mathrm{H}, \mathrm{m}, \mathrm{H}-1^{\prime \prime \prime \prime}\right)$ and $1.71\left(2 \mathrm{H}, \mathrm{m}, \mathrm{H}-2^{\prime \prime \prime \prime}\right)$, and two methyls at $\delta_{\mathrm{H}} 1.24\left(3 \mathrm{H}, \mathrm{s}, \mathrm{H}-4^{\prime \prime \prime \prime}\right)$ and $1.24\left(3 \mathrm{H}, \mathrm{s}, \mathrm{H}-5^{\prime \prime \prime \prime}\right)$ proton signals indicated the presence of a prenyl moiety. The abovementioned evidence suggested that compound 1 was a tetrahydroxyflavanone compound with a geranyl and a prenyl group. The ${ }^{13} \mathrm{C}-\mathrm{NMR}$ spectrum showed 30 carbon signals. The tetrahydroxy flavanone moiety showed one ketone signal at $\delta_{C} 198.25(\mathrm{C}-4)$, five oxygenated olefinic quaternary signals at $\delta_{\mathrm{C}} 168.85$ (C-7), 165.52 (C-8a), $165.22(\mathrm{C}-5), 154.46\left(\mathrm{C}-4^{\prime}\right)$, and 151.77 $\left(\mathrm{C}-2^{\prime}\right)$, four olefinic quaternary signals at $\delta_{\mathrm{C}} 123.40\left(\mathrm{C}-5^{\prime}\right), 119.62\left(\mathrm{C}-1^{\prime}\right), 118.74\left(\mathrm{C}-3^{\prime}\right)$, and $103.23(\mathrm{C}-4 \mathrm{a})$, three olefinic methine signals at $\delta_{C} 125.93\left(\mathrm{C}-6^{\prime}\right), 97.18(\mathrm{C}-8)$, and 96.40 (C-6), one oxygenated methine signal at $\delta_{C} 76.72(\mathrm{C}-2)$, and one methylene signal at $\delta_{\mathrm{C}} 43.35$ (C-3). Moreover, two olefinic quaternary signals at $\delta_{C} 136.44\left(C-3^{\prime \prime}\right)$ and $132.24\left(C-3^{\prime \prime \prime}\right)$, two olefinic methine signals at $\delta_{C} 125.37\left(C-2^{\prime \prime \prime}\right)$ and $123.99\left(\mathrm{C}-2^{\prime \prime}\right)$, three methylene signals at $\delta_{C} 40.90\left(\mathrm{C}-5^{\prime \prime}\right), 27.63\left(\mathrm{C}-1^{\prime \prime \prime}\right)$, and $23.77\left(\mathrm{C}-1^{\prime \prime}\right)$, and three methyl signals at $\delta_{C} 25.89\left(\mathrm{C}-4^{\prime \prime \prime}\right), 17.74\left(\mathrm{C}-5^{\prime \prime \prime}\right)$, and $16.36\left(\mathrm{C}-4^{\prime \prime}\right)$ derived from a geranyl moiety were observed. The prenyl moiety carbon signals, one oxygenated quaternary signal at $\delta_{C} 71.58\left(C-3^{\prime \prime \prime \prime}\right)$, two methylene signals at $\delta_{C} 45.05\left(C-2^{\prime \prime \prime \prime}\right)$ and $25.97\left(C-1^{\prime \prime \prime \prime}\right)$, and two methyl signals at $\delta_{C} 29.31$ $\left(\mathrm{C}-4^{\prime \prime \prime \prime}\right)$ and $29.31\left(\mathrm{C}-5^{\prime \prime \prime \prime}\right)$ were observed. The flavanone structure and the location of the geranyl and prenyl groups were determined on the basis of the COSY and HMBC NMR experiments (Figure 2). In the COSY spectrum, the oxygenated methine proton signal at $\delta_{\mathrm{H}} 5.64(\mathrm{H}-2)$ showed cross peaks with the methylene proton signals at $\delta_{\mathrm{H}} 3.08(\mathrm{H}-3 \mathrm{a})$ and $2.69(\mathrm{H}-3 \mathrm{~b})$, confirming the flavanone ring $\mathrm{C}$ structure. The two methylene proton signals at $\delta_{\mathrm{H}} 3.41\left(\mathrm{H}-1^{\prime \prime}\right)$ and $2.63\left(\mathrm{H}-1^{\prime \prime \prime \prime}\right)$ were correlated with the olefinic methine proton signal at $\delta_{\mathrm{H}} 5.18\left(\mathrm{H}-2^{\prime \prime}\right)$ and the methylene proton signal at $\delta_{\mathrm{H}} 1.71$ $\left(\mathrm{H}-2^{\prime \prime \prime \prime}\right)$, respectively. The methylene proton signal at $\delta_{\mathrm{H}} 2.06\left(\mathrm{H}-1^{\prime \prime \prime}\right)$ showed cross peaks with the olefinic methine proton signal at $\delta_{\mathrm{H}} 5.06\left(\mathrm{H}-2^{\prime \prime \prime}\right)$ and the methylene proton signal at $\delta_{\mathrm{H}} 1.98\left(\mathrm{H}-5^{\prime \prime}\right)$. In the HMBC spectrum, the allyl methylene proton signal of the geranyl moiety at $\delta_{\mathrm{H}} 3.41\left(\mathrm{H}-1^{\prime \prime}\right)$ showed cross peaks with the oxygenated olefinic quaternary carbon signals at $\delta_{\mathrm{C}} 154.46\left(\mathrm{C}-4^{\prime}\right)$ and $151.77\left(\mathrm{C}-2^{\prime}\right)$, and the olefinic quaternary carbon signal at $\delta_{C} 118.74\left(\mathrm{C}-3^{\prime}\right)$ indicating the geranyl moiety was linked to $\mathrm{C}-3^{\prime}$ in the flavanone $\mathrm{B}$ ring. The correlation of the methylene proton signal of the prenyl moiety at $\delta_{\mathrm{H}} 2.63\left(\mathrm{H}-1^{\prime \prime \prime \prime}\right)$ with the oxygenated olefinic quaternary carbon signal at $\delta_{\mathrm{C}} 154.46$ $\left(\mathrm{C}-4^{\prime}\right)$, the olefinic methine carbon signal at $\delta_{\mathrm{C}} 125.93\left(\mathrm{C}-6^{\prime}\right)$, and olefinic quaternary carbon signal at $\delta_{C} 123.40\left(C-5^{\prime}\right)$ indicated the prenyl moiety was linked to $C-5^{\prime}$ in the flavanone B ring. The absolute configuration of C-2 was determined to be $(S)$ - from positive Cotton effect at $328 \mathrm{~nm}$ and the negative Cotton effect at $279 \mathrm{~nm}$ in the CD spectrum [24]. Taken together, compound 1 was determined to be (2S)-5,7,2' , $4^{\prime}$-tetrahydroxy-3'-(3,7-dimethyl-octa-2,6-dienyl)-5'-(3-hydroxy-3-methylbutyl)flavanone, a new isoprenylated flavonoid, which was named sanggenon $\mathrm{U}$. 

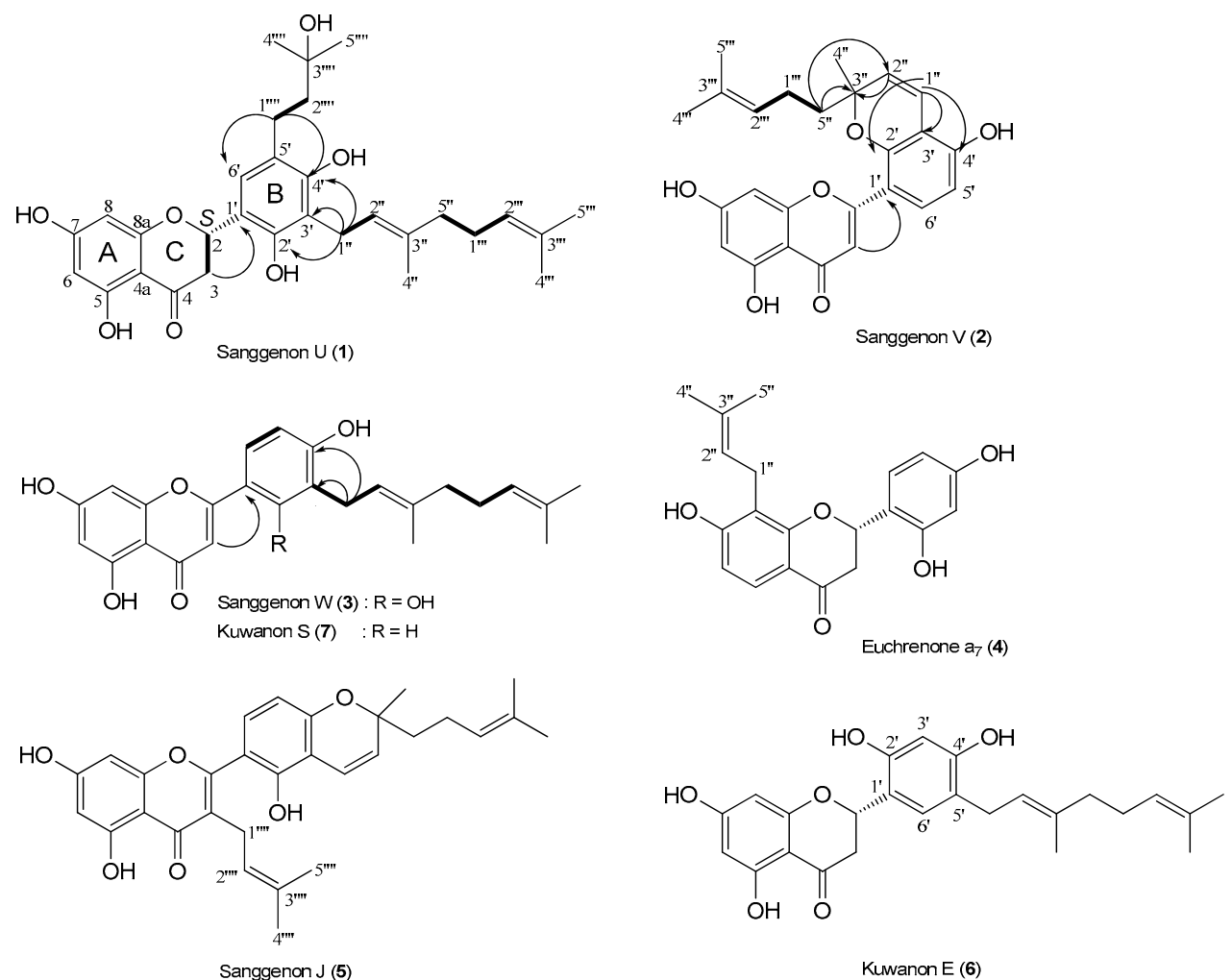

Sanggenon J (5)

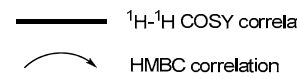

Figure 2. Chemical structures of compounds 1-7 from the root bark of Morus alba and key ${ }^{1} \mathrm{H}_{-}{ }^{1} \mathrm{H}$ COSY and $\mathrm{HMBC}$ correlations for compounds $\mathbf{1}-\mathbf{3}$.

Compound 2 was isolated as a yellow amorphous powder and showed characteristic UV absorptions at 254 and $365 \mathrm{~nm}$ in addition to a yellow color on the TLC plate when sprayed with $10 \%$ sulfuric acid and heating. The molecular weight was determined to be 420 from the molecular ion peak $m / z 420[\mathrm{M}]^{+}$in the EI/MS spectrum, and a molecular formula of $\mathrm{C}_{25} \mathrm{H}_{24} \mathrm{O}_{6}$ according to the high-resolved molecular ion peak $m / z 420.1572[\mathrm{M}]^{+}$(calcd for $\mathrm{C}_{25} \mathrm{H}_{24} \mathrm{O}_{6}, 420.1573$ ) in the HR/EI/MS. IR absorbance bands of hydroxyl $\left(3382 \mathrm{~cm}^{-1}\right)$, conjugated ketone $\left(1666 \mathrm{~cm}^{-1}\right)$, and aromatic $\left(1598,1545 \mathrm{~cm}^{-1}\right)$ groups were observed. The ${ }^{1} \mathrm{H}-\mathrm{NMR}$ spectrum exhibited two olefinic methine signals of a 1,2,3,4-tetrasubstituted benzene ring $B$ at $\delta_{\mathrm{H}} 7.62\left(1 \mathrm{H}, \mathrm{d}, J=8.4 \mathrm{~Hz}, \mathrm{H}-6^{\prime}\right)$ and $6.49\left(1 \mathrm{H}, \mathrm{d}, J=8.4 \mathrm{~Hz}, \mathrm{H}-5^{\prime}\right)$ and two olefinic methine signals of a typical meta-coupled pattern due to a 1,2,3,5-tetrasubstituted benzene ring $\mathrm{A}$ at $\delta_{\mathrm{H}} 6.38(1 \mathrm{H}$, br.s, $\mathrm{H}-8)$ and $6.17(1 \mathrm{H}$, br.s, $\mathrm{H}-6)$. The olefinic methine signal at $\delta_{\mathrm{H}} 7.04(1 \mathrm{H}, \mathrm{s}, \mathrm{H}-3)$ indicated the characteristic of flavone ring $\mathrm{C}$ structure. In addition, the olefinic methine signals at $\delta_{\mathrm{H}} 6.72\left(1 \mathrm{H}, \mathrm{d}, J=10.0 \mathrm{~Hz}, \mathrm{H}-1^{\prime \prime}\right)$ and $5.63(1 \mathrm{H}, \mathrm{d}, J=10.0 \mathrm{~Hz}$, $\mathrm{H}-2^{\prime \prime}$ ) of a prenyl moiety indicated the formation of a pyran ring through cyclization between the oxygenated olefinic quaternary carbon at $\delta_{\mathrm{C}} 110.84\left(\mathrm{C}-3^{\prime}\right)$ and the oxygenated quaternary carbon at $\delta_{C} 81.37\left(C-3^{\prime \prime}\right)$. This cyclization, a type of isoprene side chain with an ortho-phenolic hydroxyl, leads to pyrano or furano derivatives [1]. The other prenyl moiety showed one olefinic methine at $\delta_{\mathrm{H}} 5.08\left(1 \mathrm{H}, \mathrm{t}, J=6.8 \mathrm{~Hz}, \mathrm{H}-2^{\prime \prime \prime}\right)$, one methylene at $\delta_{\mathrm{H}} 2.08\left(2 \mathrm{H}, \mathrm{m}, \mathrm{H}-\mathrm{-}^{\prime \prime \prime}\right)$, and two methyls at $\delta_{\mathrm{H}} 1.58$ $\left(3 \mathrm{H}, \mathrm{s}, \mathrm{H}-4^{\prime \prime \prime}\right)$ and $1.47\left(3 \mathrm{H}, \mathrm{s}, \mathrm{H}-5^{\prime \prime \prime}\right)$ proton signals. The abovementioned evidence suggested that compound 2 was a tetrahydroxyflavone compound with a pyran ring type of prenyl substituent and a prenyl group. The ${ }^{13} \mathrm{C}-\mathrm{NMR}$ spectrum showed 25 carbon signals. The tetrahydroxyflavone moiety showed one conjugated ketone signal at $\delta_{C} 184.20$ (C-4), six oxygenated olefinic quaternary signals at $\delta_{C} 166.00$ (C-7), 163.49 (C-2), 163.06 (C-5), 159.42 (C-8a), 158.05 (C-4'), and 155.25 (C-2'), three olefinic quaternary signals at $\delta_{C} 111.53\left(\mathrm{C}-1^{\prime}\right), 110.84\left(\mathrm{C}-3^{\prime}\right)$, and $105.12(\mathrm{C}-4 \mathrm{a})$, five olefinic 
methine signals at $\delta_{C} 111.53\left(\mathrm{C}-6^{\prime}\right), 110.84\left(\mathrm{C}-3^{\prime}\right), 108.59$ (C-3), 99.92 (C-6), and 94.86 (C-8) were observed. In addition, two olefinic methines at $\delta_{C} 128.46\left(\mathrm{C}-2^{\prime \prime}\right)$ and $118.19\left(\mathrm{C}-1^{\prime \prime}\right)$, one oxygenated quaternary at $\delta_{C} 81.37\left(C-3^{\prime \prime}\right)$, one methylene at $\delta_{C} 42.17\left(C-5^{\prime \prime}\right)$, and one methyl at $\delta_{C} 26.89\left(C-4^{\prime \prime}\right)$ carbon signals were observed as the signals of a pyran ring type of a prenyl moiety. The other prenyl moiety showed one olefinic quaternary at $\delta_{C} 132.64\left(\mathrm{C}-3^{\prime \prime \prime}\right)$, one olefinic methine at $\delta_{C} 125.04$ $\left(\mathrm{C}-2^{\prime \prime \prime}\right)$, one methylene at $\delta_{\mathrm{C}} 23.98\left(\mathrm{C}-1^{\prime \prime \prime}\right)$, and two methyls at $\delta_{\mathrm{C}} 25.79\left(\mathrm{C}-4^{\prime \prime \prime}\right)$ and $17.60\left(\mathrm{C}-5^{\prime \prime \prime}\right)$ carbon signals. The flavone structure and the location of the prenyl groups were proved by COSY and HMBC NMR experiments (Figure 2). The HMBC experiment suggested the ether linkage of the pyran ring could be formed at either $\mathrm{C}-2^{\prime}$ or $\mathrm{C}-4^{\prime}$ of ring $\mathrm{B}$. Accordingly, to determine the exact position of the ether linkage in ring B, UV absorption shift experiment was carried out, which confirms the presence of the free hydroxy at C- $4^{\prime}$ of falvone B ring. Compound 2 was dissolved in $\mathrm{MeOH} / \mathrm{NaOCH}_{3}$ resulted in red shift from 259 to $281 \mathrm{~nm}$ and from 353 to $398 \mathrm{~nm}$, respectively, owing to the $4^{\prime}-\mathrm{OH}$. Therefore, the ether linkage of the pyran ring was revealed to be at $\mathrm{OH}-2^{\prime}$ of $\mathrm{B}$ ring, which was confirmed by the key correlations in the HMBC spectrum (Figure 2), that is, $\mathrm{H}-5^{\prime \prime} / \mathrm{C}-3^{\prime \prime}$ and $\mathrm{C}-2^{\prime \prime} ; \mathrm{H}-2^{\prime \prime} / \mathrm{C}-3^{\prime \prime} ; \mathrm{H}-1^{\prime \prime} / \mathrm{C}-2^{\prime}, \mathrm{C}-3^{\prime}$, and $\mathrm{C}-4^{\prime}$. Taken together, compound 2 was determined to be 5,7, $2^{\prime}, 4^{\prime}$-tetrahydroxy-2', $3^{\prime}$-(2-methyl-2-methylenechromeno)-5 ${ }^{\prime \prime}$-(3-methylbut-2-enyl)flavone, a new isoprenylated flavonoid, that was named sanggenon $\mathrm{V}$.

Compound 3 was isolated as a yellow amorphous powder and showed characteristic UV absorptions and yellow color on a TLC plate when sprayed with $10 \%$ sulfuric acid and heated. The molecular weight was determined to be 422 from the molecular ion peak $\mathrm{m} / z 422[\mathrm{M}]^{+}$in the EI/MS spectrum, and the molecular formula of $\mathrm{C}_{25} \mathrm{H}_{26} \mathrm{O}_{6}$ according to the high-resolved molecular ion peak $m / z 422.1726[\mathrm{M}]^{+}$(calcd for $\mathrm{C}_{25} \mathrm{H}_{26} \mathrm{O}_{6}, 422.1729$ ) in the HR/EI/MS. The IR absorbance bands of hydroxyl $\left(3376 \mathrm{~cm}^{-1}\right)$, conjugated ketone $\left(1659 \mathrm{~cm}^{-1}\right)$, and aromatic $\left(1588,1541 \mathrm{~cm}^{-1}\right)$ groups were observed. The ${ }^{1} \mathrm{H}-\mathrm{NMR}$ and ${ }^{13} \mathrm{C}-\mathrm{NMR}$ data of compound 3 were quite similar to those of 1 , except for the respective replacements of the oxygenated methine signal $\left(\delta_{\mathrm{H}} 5.64\right.$, $\left.\delta_{\mathrm{C}} 76.72\right)$ and the methylene signal $\left(\delta_{\mathrm{H}} 3.08,2.69, \delta_{\mathrm{C}} 43.35\right)$ in the ring $C$ of 1 by the oxygenated olefinic quaternary signal $\left(\delta_{C} 165.74\right)$ and the olefinic methine signal $\left(\delta_{H} 6.86, \delta_{C} 108.38\right)$ in 3 , and disappearance of the prenyl moiety signals at $C-5^{\prime}$ position. The carbon chemical shift of ketone signal at $C-4\left(\delta_{C} 184.16\right)$ was shifted upfield by $14.09 \mathrm{ppm}$, comparing with the carbon chemical shift of $\mathbf{1}\left(\delta_{C} 198.25\right)$ due to the conjugation effects, indicating a double bond to be between C-2 and C-3. Those findings indicated compound 3 was a tetrahydroxyflavone compound with a geranyl moiety. The tetrahydroxyflavone structure and the location of the geranyl moiety in $\mathbf{3}$ was confirmed based on the COSY and HMBC experiments (Figure 2). Thus, the structure of compound 3 was determined to be 5,7,2', 4'-tetrahydroxy-3'-(3,7-dimethyl-octa-2,6-dienyl)-flavone, a new isoprenylated flavonoid, and named sanggenon $\mathrm{W}$.

\section{Experimental Section}

\subsection{Plant Materials}

The dried root bark of Morus alba L. (Moraceae) were supplied by the Korea Food Research Institute (Sungnam, Korea) in January 2012, and was identified by Professor Dae-Keun Kim, College of Pharmacy, Woosuk University, Jeonju, Korea. A voucher specimen (KHU-NPCL-201204) has been deposited at the Laboratory of Natural Products Chemistry, Kyung Hee University, Yongin, Korea.

\subsection{General}

Open column chromatography (CC) was carried out with a Kiesel gel 60 (Merck $60 \AA$, 70-230 mesh ASTM, Darmstadt, Germany), LiChroprep RP-18 (40 60 $\mu \mathrm{m}$, Merck), and Sephadex LH-20 (Amersham Biosciences, Uppsala, Sweden). The thin layer chromatography (TLC) analysis was performed using Kieselgel $60 \mathrm{~F}_{254}$ and RP-18 $\mathrm{F}_{254 \mathrm{~S}}$ (Merck) plates. The spots on TLC were detected using a UV lamp (Spectroline Model ENF-240 C/F, Spectronics Corporation, Westbury, 
NY, USA) and a $10 \% \mathrm{H}_{2} \mathrm{SO}_{4}$ solution by spraying and heating. ${ }^{1} \mathrm{H}-(400 \mathrm{MHz})$ and ${ }^{13} \mathrm{C}-\mathrm{NMR}$ (100 MHz, nuclear magnetic resonance) spectra were recorded on a Varian Unity Inova AS-400 FT-NMR spectrometer (Palo Alto, CA, USA). Infrared (IR) spectra were obtained from a Perkin-Elmer model 599B spectrophotometer (Waltham, MA, USA). Optical rotations were measured on a polarimeter (model P-1020, JASCO, Tokyo, Japan). Electronic ionization mass spectrometry (EI/MS) and fast atom bombardment mass spectrometry (FAB/MS) spectra were obtained using a JMSAX 700 (JEOL, Tokyo, Japan). Melting points were determined using Fisher-Johns melting point apparatus (Fisher Scientific, Miami, FL, USA) and not corrected. Circular dichroism (CD) spectra were obtained from a Chirascan Plus instrument (Applied Photophysics, Surrey, UK).

\subsection{Extraction and Isolation}

The fractionation and isolation procedure is described in Figure 1. The dried root bark of M. alba $(10 \mathrm{~kg})$ was extracted with $80 \%$ methanol $(170 \mathrm{~L})$ at room temperature for $24 \mathrm{~h}$. The concentrated $\mathrm{MeOH}$ extract $(1.7 \mathrm{~kg}$ ) was suspended in $2 \mathrm{~L}$ of water and successively partitioned by increasing polarity gradients of ethyl acetate $(E t O A c, 2 \mathrm{~L} \times 2)$ and $n$-butyl alcohol $(n-\mathrm{BuOH}, 1.8 \mathrm{~L} \times 3)$. The organic and aqueous layers were concentrated to produce the EtOAc fraction (MRE, $580 \mathrm{~g}$ ), the $n-\mathrm{BuOH}$ fraction (MRB, $114 \mathrm{~g}$ ), and the $\mathrm{H}_{2} \mathrm{O}$ fraction (MRW, $1006 \mathrm{~g}$ ) residues, respectively. The MRE fraction $(122 \mathrm{~g})$ was subjected to a $\mathrm{SiO}_{2} \mathrm{CC}(\varphi 12.5 \times 15 \mathrm{~cm})$ and eluted with $n$-hexane-EtOAc $(4: 1 \rightarrow 2: 1$ $\rightarrow 1: 1,27 \mathrm{~L}$ of each) $\rightarrow \mathrm{CHCl}_{3}-\mathrm{MeOH}(10: 1,27 \mathrm{~L})$ with monitoring by TLC to obtain 41 fractions (MRE-1 to MRE-41). Fraction MRE-8 [848 mg, elution volume/total volume (Ve/Vt) $0.422-0.528$ ] was subjected to an ODS CC $(\varphi 6.5 \times 12 \mathrm{~cm})$ and eluted with $\mathrm{MeOH}-\mathrm{H}_{2} \mathrm{O}(10: 1,1.8 \mathrm{~L})$, yielding 12 fractions (MRE-8-1 to MRE-8-12). Subfraction MRE-8-4 (350 mg, Ve/Vt 0.106-0.119) was subjected to the ODS $\mathrm{CC}(\varphi 3.5 \times 12 \mathrm{~cm})$ and eluted with acetone- $\mathrm{H}_{2} \mathrm{O}(5: 2,1.1 \mathrm{~L})$, yielding 10 fractions (MRE-8-4-1 to MRE-8-4-10). Subfraction MRE-8-4-8 (40 mg, Ve/Vt 0.710-0.747) was subjected to a Sephadex LH-20 $\mathrm{CC}(\varphi 1.5 \times 60 \mathrm{~cm})$ and eluted with $\mathrm{MeOH}-\mathrm{H}_{2} \mathrm{O}(4: 1,0.5 \mathrm{~L})$, yielding six fractions (MRE-8-4-8-1 to MRE-8-4-8-6) including a purified compound 5 at MRE-8-4-8-3 [16 mg, Ve/Vt 0.315-0.489, TLC (ODS) $\mathrm{R}_{\mathrm{f}} 0.55$, acetone- $\left.\mathrm{H}_{2} \mathrm{O}=5: 1\right]$. Fraction MRE-23 (848 mg, Ve/ $\left.\mathrm{Vt} 0.422-0.528\right)$ was applied to the ODS CC $(\varphi 4.5 \times 6 \mathrm{~cm})$ and eluted with $\mathrm{MeOH}-\mathrm{H}_{2} \mathrm{O}(3: 1 \rightarrow 8: 1,3 \mathrm{~L}$ of each), yielding 12 fractions (MRE-23-1 to MRE-23-12). Subfraction MRE-23-6 (60 mg, Ve/Vt 0.422-0.528) was subjected to the Sephadex LH-20 CC $(\varphi 1.5 \times 57 \mathrm{~cm})$ and eluted with $\mathrm{MeOH}-\mathrm{H}_{2} \mathrm{O}(4: 1,2 \mathrm{~L})$, yielding seven fractions (MRE-23-6-1 to MRE-23-6-7) including a purified compound 1 at MRE-23-6-6 [10 mg, Ve/Vt 0.864-0.903, TLC (ODS) $\left.\mathrm{R}_{\mathrm{f}} 0.55, \mathrm{MeOH}-\mathrm{H}_{2} \mathrm{O}=10: 1\right]$. Subfraction MRE-23-7 (400 mg, Ve/Vt 0.136-0.318) was subjected to the Sephadex LH-20 CC $(\varphi 1.5 \times 60 \mathrm{~cm})$ and eluted with $\mathrm{MeOH}-\mathrm{H}_{2} \mathrm{O}(4: 1,2.1 \mathrm{~L})$, yielding 10 fractions (MRE-23-7-1 to MRE-23-7-10) including a purified compound 6 at MRE-23-7-8 [42 mg, Ve/Vt 0.760-0.833, TLC (ODS) $\mathrm{R}_{\mathrm{f}}$ 0.44, $\mathrm{MeOH}-\mathrm{H}_{2} \mathrm{O}=6: 1$ ]. Subfraction MRE-23-8 (110 mg, $\mathrm{Ve} / \mathrm{Vt} 0.319-0.506)$ was subjected to the Sephadex LH-20 CC $(\varphi 2 \times 67 \mathrm{~cm})$ and eluted with $\mathrm{MeOH}-\mathrm{H}_{2} \mathrm{O}$ (4:1, 2 L), yielding 10 fractions (MRE-23-8-1 to MRE-23-8-10) including a purified compound 2 at MRE-23-8-5 [15 mg, Ve/Vt 0.523-0.553, TLC (ODS) $\left.\mathrm{R}_{\mathrm{f}} 0.43, \mathrm{MeOH}-\mathrm{H}_{2} \mathrm{O}=10: 1\right]$ and a compound 3 at

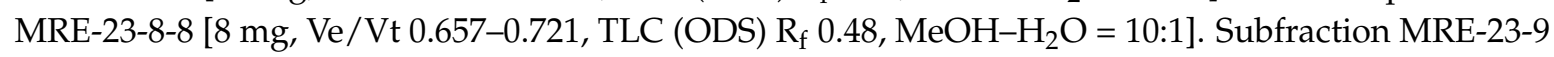
$(120 \mathrm{mg}, \mathrm{Ve} / \mathrm{Vt}$ 0.507-0.651) was subjected to the Sephadex LH-20 CC $(\varphi 1.5 \times 60 \mathrm{~cm})$ and eluted with $\mathrm{MeOH}-\mathrm{H}_{2} \mathrm{O}$ (4:1, 0.7 L), yielding five fractions (MRE-23-9-1 to MRE-23-9-5). Subfraction MRE-23-9-4 (52 mg, Ve/Vt 0.704-0.795) was subjected to the $\mathrm{SiO}_{2} \mathrm{CC}(\varphi 2 \times 15 \mathrm{~cm})$ and eluted with $\mathrm{CHCl}_{3}-\mathrm{MeOH}$ (22:1, 0.4 L), yielding nine fractions (MRE-23-9-4-1 to MRE-23-9-4-9) including a purified compound 7 at MRE-23-9-4-4 [15 mg, Ve/Vt 0.505-0.555, TLC (ODS) $\left.\mathrm{R}_{\mathrm{f}} 0.41, \mathrm{MeOH}-\mathrm{H}_{2} \mathrm{O}=12: 1\right]$. Fraction MRE-28 $(2.2 \mathrm{~g}, \mathrm{Ve} / \mathrm{Vt} 0.595-0.670)$ was applied to the ODS CC $(\varphi 7 \times 4 \mathrm{~cm})$ and eluted with $\mathrm{MeOH}-\mathrm{H}_{2} \mathrm{O}$ (2:1 $\rightarrow 4: 1 \rightarrow 6: 1,2 \mathrm{~L}$ of each), yielding 16 fractions (MRE-28-1 to MRE-28-16). Subfraction MRE-28-3 ( $80 \mathrm{mg}, \mathrm{Ve} / \mathrm{Vt}$ 0.021-0.032) was subjected to the Sephadex LH-20 CC $(\varphi 1 \times 60 \mathrm{~cm})$ and eluted with $\mathrm{MeOH}-\mathrm{H}_{2} \mathrm{O}$ (7:3, $1 \mathrm{~L}$ ), yielding 10 fractions (MRE-28-3-1 to MRE-28-3-10) along with a purified compound 4 at MRE-28-3-4 (8 mg, Ve/Vt 0.214-0.283, TLC (ODS) $\mathrm{R}_{\mathrm{f}} 0.55, \mathrm{MeOH}-\mathrm{H}_{2} \mathrm{O}=2: 1$ ). 


\subsection{Spectroscopic Data}

Sanggenon $U$ (1). Yellow amorphous powder (MeOH). m.p. $155-160^{\circ} \mathrm{C} .[\alpha]_{\mathrm{D}}^{25}-39.7^{\circ}(c 0.62, \mathrm{MeOH})$. $\mathrm{IR}_{v}\left(\mathrm{CaF}_{2}\right.$ plate) $3373,2924,1662,1608,1577 \mathrm{~cm}^{-1}$. HR/EI/MS m/z $510.2616[\mathrm{M}]^{+}$(calcd for $\mathrm{C}_{30} \mathrm{H}_{38} \mathrm{O}_{7}$, 510.2618). ${ }^{1} \mathrm{H}-\mathrm{NMR}\left(\mathrm{CD}_{3} \mathrm{OD}\right)$ and ${ }^{13} \mathrm{C}-\mathrm{NMR}\left(\mathrm{CD}_{3} \mathrm{OD}\right)$ data: see Table 1.

Sanggenon $V$ (2). Yellow amorphous powder $(\mathrm{MeOH})$. m.p. $145-150{ }^{\circ} \mathrm{C} .[\alpha]_{\mathrm{D}}^{25}+2 \cdot 1^{\circ}(c 0.85, \mathrm{MeOH})$. $\mathrm{IR}_{v}\left(\mathrm{CaF}_{2}\right.$ plate) 3382, 2944, 2863, 1666, 1598, $1545 \mathrm{~cm}^{-1}$. HR/EI/MS $m / z 420.1572[\mathrm{M}]^{+}$(calcd for $\left.\mathrm{C}_{25} \mathrm{H}_{24} \mathrm{O}_{6}, 420.1573\right) .{ }^{1} \mathrm{H}-\mathrm{NMR}\left(\mathrm{CD}_{3} \mathrm{OD}\right)$ and ${ }^{13} \mathrm{C}-\mathrm{NMR}\left(\mathrm{CD}_{3} \mathrm{OD}\right)$ data: see Table 1.

Sanggenon $W$ (3). Yellow amorphous powder (MeOH). m.p. 100-105 ${ }^{\circ} \mathrm{C} . \mathrm{IR}_{v}\left(\mathrm{CaF}_{2}\right.$ plate) 3376, 2935, 2869, 1659, 1588, $1541 \mathrm{~cm}^{-1}$. HR/EI/MS $\mathrm{m} / z 422.1726$ [M] ${ }^{+}$(calcd for $\left.\mathrm{C}_{25} \mathrm{H}_{26} \mathrm{O}_{6}, 422.1729\right) .{ }^{1} \mathrm{H}-\mathrm{NMR}$ $\left(\mathrm{CD}_{3} \mathrm{OD}\right)$ and ${ }^{13} \mathrm{C}-\mathrm{NMR}\left(\mathrm{CD}_{3} \mathrm{OD}\right)$ data: see Table 1.

Euchrenone $a_{7}$ (4). Yellow amorphous powder (MeOH). m.p. $110-115^{\circ} \mathrm{C} .[\alpha]_{\mathrm{D}}^{25}-34.8^{\circ}(c 0.45, \mathrm{MeOH})$. $\mathrm{IR}_{v}\left(\mathrm{CaF}_{2}\right.$ plate $) 3310,2922,2887,1667,1601,1518 \mathrm{~cm}^{-1}$. EI/MS m/z $340[\mathrm{M}]^{+} .{ }^{1} \mathrm{H}-\mathrm{NMR}\left(\mathrm{CD}_{3} \mathrm{OD}\right.$, $\left.\delta_{\mathrm{H}}\right) 7.58(1 \mathrm{H}, \mathrm{d}, J=8.8 \mathrm{~Hz}, \mathrm{H}-5), 7.27\left(1 \mathrm{H}, \mathrm{d}, J=8.8 \mathrm{~Hz}, \mathrm{H}-6^{\prime}\right), 6.50(1 \mathrm{H}, \mathrm{d}, J=8.8 \mathrm{~Hz}, \mathrm{H}-6), 6.33(1 \mathrm{H}$, $\left.\mathrm{dd}, J=8.8,2.0 \mathrm{~Hz}, \mathrm{H}-5^{\prime}\right), 6.32\left(1 \mathrm{H}, \mathrm{d}, J=2.0 \mathrm{~Hz}, \mathrm{H}-3^{\prime}\right), 5.60(1 \mathrm{H}, \mathrm{dd}, J=13.2,2.8 \mathrm{~Hz}, \mathrm{H}-2), 5.19(1 \mathrm{H}$, $\left.\mathrm{t}, J=6.8 \mathrm{~Hz}, \mathrm{H}-2^{\prime \prime}\right), 3.28\left(2 \mathrm{H}, \mathrm{m}, \mathrm{H}-1^{\prime \prime}\right), 2.92(1 \mathrm{H}, \mathrm{dd}, J=17.2,13.2 \mathrm{~Hz}, \mathrm{H}-3 \mathrm{a}), 2.72(1 \mathrm{H}, \mathrm{dd}, J=17.2$, $2.8 \mathrm{~Hz}, \mathrm{H}-3 \mathrm{~b}), 1.75\left(3 \mathrm{H}, \mathrm{s}, \mathrm{H}-4^{\prime \prime}\right), 1.75\left(3 \mathrm{H}, \mathrm{s}, \mathrm{H}-5^{\prime \prime}\right) ;{ }^{13} \mathrm{C}-\mathrm{NMR}\left(\mathrm{CD}_{3} \mathrm{OD}, \delta_{\mathrm{C}}\right) 195.03$ (C-4), 163.84 (C-8a), $163.57(\mathrm{C}-7), 159.51\left(\mathrm{C}-4^{\prime}\right), 156.65\left(\mathrm{C}-2^{\prime}\right), 132.11\left(\mathrm{C}-3^{\prime \prime}\right), 128.65\left(\mathrm{C}-6^{\prime}\right), 126.74(\mathrm{C}-5), 123.38\left(\mathrm{C}-2^{\prime \prime}\right), 118.57$ (C-1'), 117.13 (C-8), 115.02 (C-4a), 110.69 (C-6), 107.64 (C-3'), 103.36 (C-5'), 76.29 (C-2), 44.03 (C-3), 25.98 $\left(\mathrm{C}-4^{\prime \prime}\right), 22.99\left(\mathrm{C}-1^{\prime \prime}\right), 17.95\left(\mathrm{C}-5^{\prime \prime}\right)$.

Sanggenon J (5). Yellow amorphous powder (MeOH). m.p. $140-145{ }^{\circ} \mathrm{C} .[\alpha]_{\mathrm{D}}^{21}-16.9^{\circ}\left(c 0.03, \mathrm{CHCl}_{3}\right)$. EI/MS $m / z 488[\mathrm{M}]^{+}$. IR $\left(\mathrm{CaF}_{2}\right.$ plate, $\left.v\right) 3374,2928,2892,1661,1605,1514 \mathrm{~cm}^{-1} .{ }^{1} \mathrm{H}-\mathrm{NMR}\left(\mathrm{CD}_{3} \mathrm{OD}\right.$, $\left.\delta_{\mathrm{H}}\right) 6.97\left(1 \mathrm{H}, \mathrm{d}, J=8.4 \mathrm{~Hz}, \mathrm{H}-6^{\prime}\right), 6.75\left(1 \mathrm{H}, \mathrm{d}, J=10.0 \mathrm{~Hz}, \mathrm{H}-1^{\prime \prime}\right), 6.39\left(1 \mathrm{H}, \mathrm{d}, J=8.4 \mathrm{~Hz}, \mathrm{H}-5^{\prime}\right), 6.26(1 \mathrm{H}$, $\mathrm{d}, J=2.4 \mathrm{~Hz}, \mathrm{H}-8), 6.17(1 \mathrm{H}, \mathrm{d}, J=2.4 \mathrm{~Hz}, \mathrm{H}-6), 5.63\left(1 \mathrm{H}, \mathrm{d}, J=10.0 \mathrm{~Hz}, \mathrm{H}-2^{\prime \prime}\right), 5.09(1 \mathrm{H}, \mathrm{t}, J=6.8 \mathrm{~Hz}$, $\left.\mathrm{H}-2^{\prime \prime \prime}\right), 5.07\left(1 \mathrm{H}, \mathrm{t}, J=6.8 \mathrm{~Hz}, \mathrm{H}-2^{\prime \prime \prime \prime}\right), 3.07\left(2 \mathrm{H}, \mathrm{d}, J=6.8 \mathrm{~Hz}, \mathrm{H}-1^{\prime \prime \prime \prime}\right), 2.11(2 \mathrm{H}, \mathrm{dt}, J=7.2,6.8 \mathrm{~Hz}$, $\left.\mathrm{H}-1^{\prime \prime \prime}\right), 1.71\left(2 \mathrm{H}, \mathrm{t}, J=7.2 \mathrm{~Hz}, \mathrm{H}-5^{\prime \prime}\right), 1.65\left(3 \mathrm{H}, \mathrm{s}, \mathrm{H}-5^{\prime \prime \prime}\right), 1.58\left(3 \mathrm{H}, \mathrm{s}, \mathrm{H}-4^{\prime \prime \prime}\right), 1.56\left(3 \mathrm{H}, \mathrm{s}, \mathrm{H}-5^{\prime \prime \prime \prime}\right), 1.39$ $\left(3 \mathrm{H}, \mathrm{s}, \mathrm{H}-4^{\prime \prime}\right), 1.33\left(3 \mathrm{H}, \mathrm{s}, \mathrm{H}-4^{\prime \prime \prime \prime}\right) ;{ }^{13} \mathrm{C}-\mathrm{NMR}\left(\mathrm{CD}_{3} \mathrm{OD}, \delta_{\mathrm{C}}\right) 183.66(\mathrm{C}-4), 165.61(\mathrm{C}-7), 163.27$ (C-5), 162.81 (C-2), 159.94 (C-8a), $157.36\left(\mathrm{C}-4^{\prime}\right), 151.92\left(\mathrm{C}-2^{\prime}\right), 132.83\left(\mathrm{C}-3^{\prime \prime \prime \prime}\right), 132.49\left(\mathrm{C}-3^{\prime \prime \prime}\right), 131.24\left(\mathrm{C}-6^{\prime}\right), 129.35$ $\left(\mathrm{C}-2^{\prime \prime}\right), 125.24\left(\mathrm{C}-2^{\prime \prime \prime}\right), 122.52\left(\mathrm{C}-2^{\prime \prime \prime \prime}\right), 122.23(\mathrm{C}-3), 118.14\left(\mathrm{C}-1^{\prime \prime}\right), 114.97\left(\mathrm{C}-1^{\prime}\right), 111.72\left(\mathrm{C}-3^{\prime}\right), 109.33$ $\left(\mathrm{C}-5^{\prime}\right), 105.50(\mathrm{C}-4 \mathrm{a}), 99.56(\mathrm{C}-6), 94.61(\mathrm{C}-8), 79.67\left(\mathrm{C}-3^{\prime \prime}\right), 42.19\left(\mathrm{C}-5^{\prime \prime}\right), 26.76\left(\mathrm{C}-4^{\prime \prime \prime \prime}\right), 25.85\left(\mathrm{C}-5^{\prime \prime \prime}\right)$, $25.85\left(\mathrm{C}-5^{\prime \prime \prime \prime}\right), 24.68\left(\mathrm{C}--^{\prime \prime \prime \prime}\right), 23.75\left(\mathrm{C}-1^{\prime \prime}\right), 17.69\left(\mathrm{C}-4^{\prime \prime \prime}\right), 17.63\left(\mathrm{C}-4^{\prime \prime \prime \prime}\right)$.

Kuwanon E (6). Yellow amorphous powder (MeOH). m.p. $120-125^{\circ} \mathrm{C} .[\alpha]_{\mathrm{D}}^{25}-0.25^{\circ}\left(c 0.29, \mathrm{CH}_{3} \mathrm{OH}\right)$. EI/MS $m / z 424[\mathrm{M}]^{+}$. IR $\left(\mathrm{CaF}_{2}\right.$ plate, $\left.v\right) 3379,2922,2889,1666,1612,1588 \mathrm{~cm}^{-1} .{ }^{1} \mathrm{H}-\mathrm{NMR}\left(\mathrm{CD}_{3} \mathrm{OD}\right.$, $\left.\delta_{\mathrm{H}}\right) 7.06\left(1 \mathrm{H}, \mathrm{s}, \mathrm{H}-6^{\prime}\right), 6.33\left(1 \mathrm{H}, \mathrm{d}, J=8.4 \mathrm{~Hz}, \mathrm{H}-3^{\prime}\right), 5.89(1 \mathrm{H}, \mathrm{d}, J=2.4 \mathrm{~Hz}, \mathrm{H}-6), 5.86(1 \mathrm{H}, \mathrm{d}, J=2.4 \mathrm{~Hz}$, $\mathrm{H}-8), 5.58(1 \mathrm{H}, \mathrm{dd}, J=13.2,2.8 \mathrm{~Hz}, \mathrm{H}-2), 5.28\left(1 \mathrm{H}, \mathrm{t}, J=6.8 \mathrm{~Hz}, \mathrm{H}-2^{\prime \prime}\right), 5.08\left(1 \mathrm{H}, \mathrm{t}, J=6.8 \mathrm{~Hz}, \mathrm{H}-2^{\prime \prime \prime}\right)$, $3.19\left(2 \mathrm{H}, \mathrm{d}, J=7.2 \mathrm{~Hz}, \mathrm{H}-\mathrm{-}^{\prime \prime}\right), 3.03(1 \mathrm{H}, \mathrm{dd}, J=17.2,13.2 \mathrm{~Hz}, \mathrm{H}-3 \mathrm{a}), 2.68(1 \mathrm{H}, \mathrm{dd}, J=17.2,2.8 \mathrm{~Hz}, \mathrm{H}-3 \mathrm{~b})$, $2.07\left(2 \mathrm{H}, \mathrm{dt}, J=7.2,6.8 \mathrm{~Hz}, \mathrm{H}-\mathrm{-}^{\prime \prime \prime}\right), 2.00\left(2 \mathrm{H}, \mathrm{t}, J=7.2 \mathrm{~Hz}, \mathrm{H}-5^{\prime \prime}\right), 1.66\left(3 \mathrm{H}, \mathrm{s}, \mathrm{H}-4^{\prime \prime}\right), 1.59\left(3 \mathrm{H}, \mathrm{s}, \mathrm{H}-4^{\prime \prime \prime}\right)$, $1.55\left(3 \mathrm{H}, \mathrm{s}, \mathrm{H}-5^{\prime \prime \prime}\right) ;{ }^{13} \mathrm{C}-\mathrm{NMR}\left(\mathrm{CD}_{3} \mathrm{OD}, \delta_{\mathrm{C}}\right) 198.45$ (C-4), 168.20 (C-8a), 165.43 (C-7), 165.35 (C-5), 156.95 $\left(\mathrm{C}-4^{\prime}\right), 154.42\left(\mathrm{C}-2^{\prime}\right), 136.44\left(\mathrm{C}-3^{\prime \prime}\right), 132.11\left(\mathrm{C}-3^{\prime \prime \prime}\right), 128.65\left(\mathrm{C}-6^{\prime}\right), 125.41\left(\mathrm{C}-2^{\prime \prime \prime}\right), 124.39\left(\mathrm{C}-2^{\prime \prime}\right), 120.55$ $\left(\mathrm{C}-5^{\prime}\right), 117.29\left(\mathrm{C}-1^{\prime}\right), 103.35$ (C-3'), 103.34 (C-4a), 96.88 (C-6), 96.17 (C-8), 76.07 (C-2), 43.13 (C-3), 40.85 $\left(\mathrm{C}-5^{\prime \prime}\right), 28.44\left(\mathrm{C}-1^{\prime \prime}\right), 27.77\left(\mathrm{C}-1^{\prime \prime \prime}\right), 25.86\left(\mathrm{C}-4^{\prime \prime \prime}\right), 17.76\left(\mathrm{C}-5^{\prime \prime \prime}\right), 16.18\left(\mathrm{C}-4^{\prime \prime}\right)$.

Kuwanon $S$ (7). Yellow amorphous powder (MeOH). m.p. $78-80{ }^{\circ} \mathrm{C}$. EI/MS m/z $406[\mathrm{M}]^{+}$. IR $\left(\mathrm{CaF}_{2}\right.$ plate, v) 3359, 2913, 2884, 1671, 1601, $1584 \mathrm{~cm}^{-1} .{ }^{1} \mathrm{H}-\mathrm{NMR}\left(\mathrm{CD}_{3} \mathrm{OD}, \delta_{\mathrm{H}}\right) 7.59\left(1 \mathrm{H}, \mathrm{d}, J=8.8 \mathrm{~Hz}, \mathrm{H}-6^{\prime}\right)$, $7.58\left(1 \mathrm{H}\right.$, br.s, H-2'), $6.84\left(1 \mathrm{H}, \mathrm{d}, J=8.8 \mathrm{~Hz}, \mathrm{H}-5^{\prime}\right), 6.44(1 \mathrm{H}, \mathrm{s}, \mathrm{H}-3), 6.36(1 \mathrm{H}$, br.s, H-6), 6.15 (1H, br.s, $\mathrm{H}-8), 5.32\left(1 \mathrm{H}, \mathrm{t}, J=6.8 \mathrm{~Hz}, \mathrm{H}-2^{\prime \prime}\right), 5.09\left(1 \mathrm{H}, \mathrm{t}, J=6.8 \mathrm{~Hz}, \mathrm{H}-2^{\prime \prime \prime}\right), 3.31\left(2 \mathrm{H}, \mathrm{d}, J=7.2 \mathrm{~Hz}, \mathrm{H}-1^{\prime \prime}\right), 2.11(2 \mathrm{H}$, 
$\left.\mathrm{dt}, J=7.2,6.8 \mathrm{~Hz}, \mathrm{H}-1^{\prime \prime \prime}\right), 2.05\left(2 \mathrm{H}, \mathrm{t}, J=7.2 \mathrm{~Hz}, \mathrm{H}-5^{\prime \prime}\right), 1.72\left(3 \mathrm{H}, \mathrm{s}, \mathrm{H}-4^{\prime \prime}\right), 1.59\left(3 \mathrm{H}, \mathrm{s}, \mathrm{H}-4^{\prime \prime \prime}\right), 1.56(3 \mathrm{H}$, s, H-5 $\left.{ }^{\prime \prime \prime}\right) ;{ }^{13} \mathrm{C}-\mathrm{NMR}\left(\mathrm{CD}_{3} \mathrm{OD}, \delta_{\mathrm{C}}\right) 183.72(\mathrm{C}-4), 166.44(\mathrm{C}-2), 166.03(\mathrm{C}-7), 163.11(\mathrm{C}-5), 160.51\left(\mathrm{C}-4^{\prime}\right)$, 159.30 (C-8a), $137.64\left(\mathrm{C}-3^{\prime \prime}\right), 132.11\left(\mathrm{C}-3^{\prime \prime \prime}\right), 130.28\left(\mathrm{C}-3^{\prime}\right), 128.79\left(\mathrm{C}-6^{\prime}\right), 126.81\left(\mathrm{C}-2^{\prime \prime \prime}\right), 125.26\left(\mathrm{C}-2^{\prime \prime \prime}\right)$, $123.26\left(\mathrm{C}-2^{\prime \prime}\right), 116.17\left(\mathrm{C}-5^{\prime}\right), 105.21$ (C-4a), 103.53 (C-3), 100.11 (C-6), 95.05 (C-8), $40.86\left(\mathrm{C}-5^{\prime \prime}\right), 28.99$ $\left(\mathrm{C}-1^{\prime \prime}\right), 27.70\left(\mathrm{C}-1^{\prime \prime \prime}\right), 25.85\left(\mathrm{C}-4^{\prime \prime \prime}\right), 17.79\left(\mathrm{C}-5^{\prime \prime \prime}\right), 16.27\left(\mathrm{C}-4^{\prime \prime}\right)$.

Table 1. ${ }^{1} \mathrm{H}$ - and ${ }^{13} \mathrm{C}-\mathrm{NMR}$ data $\left(400\right.$ and $100 \mathrm{MHz}$, resp.; $\mathrm{CD}_{3} \mathrm{OD}$ ) of isoprenylated flavonoids 1-3 from the root bark of Morus alba.

\begin{tabular}{|c|c|c|c|c|c|c|}
\hline & \multicolumn{2}{|l|}{ Compound 1} & \multicolumn{2}{|l|}{ Compound 2} & \multicolumn{2}{|l|}{ Compound 3} \\
\hline 2 & $\begin{array}{c}\delta_{\mathrm{H}} \\
5.64(\mathrm{dd}, J=12.8,2.8 \mathrm{~Hz})\end{array}$ & $\begin{array}{c}\delta_{C} \\
76.72\end{array}$ & $\delta_{\mathrm{H}}$ & $\begin{array}{c}\delta_{C} \\
163.49\end{array}$ & $\delta_{\mathrm{H}}$ & $\begin{array}{c}\delta_{C} \\
165.74\end{array}$ \\
\hline 3 & $\begin{array}{c}3.08(\mathrm{dd}, J=17.2,12.8 \mathrm{~Hz}) \\
2.69(\mathrm{dd}, J=17.2,2.8 \mathrm{~Hz})\end{array}$ & 43.35 & $7.04(\mathrm{~s})$ & 108.59 & $6.86(\mathrm{~s})$ & 108.38 \\
\hline 4 & & 198.25 & & 184.20 & & 184.16 \\
\hline $4 a$ & & 103.23 & & 105.12 & & 105.13 \\
\hline 5 & & 165.22 & & 163.06 & & 163.09 \\
\hline 6 & $5.90(\mathrm{~d}, J=2.0 \mathrm{~Hz})$ & 96.40 & $6.17(\mathrm{~s})$ & 99.92 & $6.17(\mathrm{~s})$ & 100.04 \\
\hline 7 & & 168.85 & & 166.00 & & 166.27 \\
\hline 8 & $5.86(\mathrm{~d}, J=2.0 \mathrm{~Hz})$ & 97.18 & $6.38(\mathrm{~s})$ & 94.86 & $6.39(\mathrm{~s})$ & 95.08 \\
\hline $8 \mathrm{a}$ & & 165.52 & & 159.42 & & 159.67 \\
\hline $1^{\prime}$ & & 119.62 & & 111.53 & & 112.62 \\
\hline $2^{\prime}$ & & 151.77 & & 155.25 & & 160.87 \\
\hline $3^{\prime}$ & & 118.74 & & 110.84 & & 118.10 \\
\hline $4^{\prime}$ & & 154.46 & & 158.05 & & 156.70 \\
\hline $5^{\prime}$ & & 123.40 & $6.49(\mathrm{~d}, J=8.4 \mathrm{~Hz})$ & 109.41 & $6.50(\mathrm{~d}, J=8.4 \mathrm{~Hz})$ & 109.20 \\
\hline $6^{\prime}$ & $7.03(\mathrm{~s})$ & 125.93 & $7.62(\mathrm{~d}, J=8.4 \mathrm{~Hz})$ & 129.80 & $7.46(\mathrm{~d}, J=8.4 \mathrm{~Hz})$ & 128.25 \\
\hline $1^{\prime \prime}$ & $3.41(\mathrm{~d}, J=6.8 \mathrm{~Hz})$ & 23.77 & $6.72(\mathrm{~d}, J=10.0 \mathrm{~Hz})$ & 118.19 & $3.40(\mathrm{~d}, J=6.8 \mathrm{~Hz})$ & 23.05 \\
\hline $2^{\prime \prime}$ & $5.18(\mathrm{t}, J=6.8 \mathrm{~Hz})$ & 123.99 & $5.63(\mathrm{~d}, J=10.0 \mathrm{~Hz})$ & 128.46 & $5.20(\mathrm{t}, J=6.8 \mathrm{~Hz})$ & 123.49 \\
\hline $3^{\prime \prime}$ & & 136.44 & & 81.37 & & 136.45 \\
\hline $4^{\prime \prime}$ & $1.78(\mathrm{~s})$ & 16.36 & $1.47(\mathrm{~s})$ & 26.89 & $1.78(\mathrm{~s})$ & 16.36 \\
\hline $5^{\prime \prime}$ & $1.98(\mathrm{~d}, J=6.8 \mathrm{~Hz})$ & 40.90 & $\begin{array}{l}1.79(\mathrm{~m}) \\
1.69(\mathrm{~m})\end{array}$ & 42.17 & $1.97(\mathrm{t}, J=6.8 \mathrm{~Hz})$ & 40.91 \\
\hline $1^{\prime \prime \prime}$ & $2.06(\mathrm{dt}, J=6.8,6.8 \mathrm{~Hz})$ & 27.63 & $2.08(\mathrm{~m})$ & 23.98 & $2.05(\mathrm{dt}, J=6.8,6.8 \mathrm{~Hz})$ & 27.67 \\
\hline $2^{\prime \prime \prime}$ & $5.06(\mathrm{t}, J=6.8 \mathrm{~Hz})$ & 125.37 & $5.08(\mathrm{t}, J=6.8 \mathrm{~Hz})$ & 125.04 & $5.05(\mathrm{t}, J=6.8 \mathrm{~Hz})$ & 125.38 \\
\hline $3^{\prime \prime \prime}$ & & 132.24 & & 132.64 & & 132.19 \\
\hline $4^{\prime \prime \prime}$ & $1.62(\mathrm{~s})$ & 25.89 & $1.58(\mathrm{~s})$ & 25.79 & 1.59 (s) & 25.85 \\
\hline $5^{\prime \prime \prime}$ & $1.56(\mathrm{~s})$ & 17.74 & $1.47(\mathrm{~s})$ & 17.60 & $1.54(\mathrm{~s})$ & 17.72 \\
\hline $1^{\prime \prime \prime \prime \prime}$ & $2.63(\mathrm{~m})$ & 25.97 & & & & \\
\hline $2^{\prime \prime \prime \prime \prime}$ & $1.71(\mathrm{~m})$ & 45.05 & & & & \\
\hline $3^{\prime \prime \prime \prime \prime}$ & & 71.58 & & & & \\
\hline $4^{\prime \prime \prime \prime \prime}$ & $1.24(\mathrm{~s})$ & 29.31 & & & & \\
\hline $5^{\prime \prime \prime \prime \prime}$ & $1.24(\mathrm{~s})$ & 29.31 & & & & \\
\hline
\end{tabular}

\section{Conclusions}

Three new isoprenylated flavonoids 1-3 and four known ones 4-7 were isolated from the root bark of M. alba. Chemical structures of the isolated compounds were identified on the basis of NMR, MS, CD, and IR spectroscopic data. Compounds 1-4 were isolated for the first time from the root bark of M. alba in this study.

Supplementary Materials: ${ }^{1} \mathrm{H}-\mathrm{NMR},{ }^{13} \mathrm{C}-\mathrm{NMR}, \mathrm{HMBC}$, and MS spectra are available as supporting data. Supplementary materials can be accessed at: http://www.mdpi.com/1420-3049/21/9/1112/s1.

Acknowledgments: This work was carried out with the support of "Cooperative Research Program for Agriculture Science \& Technology Development (Project No. PJ01133302)" Rural Development Administration, Korea.

Author Contributions: N.-I.B. and D.H. designed research; J.-H.P., Y.-G.L., K.-H.S., E.-J.O., D.-Y.L., and D.-W.L. performed research and analyzed the data; J.-W.J. wrote the paper. All authors read and approved the final manuscript.

Conflicts of Interest: The authors declare no conflict of interest. 


\section{References}

1. Barron, D.; Ibrahim, R.K. Isoprenylated flavonoids-A survey. Phytochemistry 1996, 43, 921-982. [CrossRef]

2. Huang, X.; Zhu, D.; Lou, Y. A novel anticancer agent, icaritin, induced cell growth inhibition, G1 arrest and mitochondrial transmembrane potential drop in human prostate carcinoma PC-3 cells. Eur. J. Pharmacol. 2007, 564, 26-36. [CrossRef] [PubMed]

3. Lee, K.; Lee, D.H.; Jung, Y.J.; Shin, S.Y.; Lee, Y.H. The natural flavone eupatorin induces cell cycle arrest at the G2/M phase and apoptosis in HeLa cells. Appl. Biol. Chem. 2016, 59, 193-199. [CrossRef]

4. Han, A.R.; Kang, Y.J.; Windono, T.; Lee, S.K.; Seo, E.K. Prenylated flavonoids from the heartwood of Artocarpus communis with inhibitory activity on lipopolysaccharide-induced nitric oxide production. J. Nat. Prod. 2006, 69, 719-721. [CrossRef] [PubMed]

5. Maitrejean, M.; Comte, G.; Barron, D.; El Kirat, K.; Conseil, G.; Di Pietro, A. The flavanolignan silybin and its hemisynthetic derivatives, a novel series of potential modulators of P-glycoprotein. Bioorg. Med. Chem. Lett. 2000, 10, 157-160. [CrossRef]

6. Jung, J.W.; Park, J.H.; Seo, K.H.; Oh, E.J.; Baek, N.I.; Ko, W.M.; Kim, Y.C.; Lee, D.Y.; Lee, D.S.; Lim, D.W. Isoprenylated flavonoids from the root bark of Morus alba and their hepatoprotective and neuroprotective activities. Arch. Pharm. Res. 2015, 38, 2066-2075. [CrossRef] [PubMed]

7. Srivastava, A.; Elangovan, V. Nutritive contents of different varieties of mulberry leaves. J. Sci. Nat. 2011, 2, 254-258.

8. Zhu, Y.P. Chinese Materia Medica; Harwood Academic Publisher: Amsterdam, The Netherlands, 1998; pp. 505-507.

9. Hano, Y.; Suzuki, S.; Nomura, T.; Litakam, Y. Absolute configuration of natural diels-alder type adducts from the Morus root bark. Heterocycles 1988, 27, 2315-2325.

10. Jiang, D.; He, Z.D.; Jiang, R.W.; Ye, W.C.; Xu, H.X.; But, P. Antiviral flavonoids from the root bark of Morus alba L. Phytochemistry 2003, 62, 1235-1238.

11. Jung, J.W.; Park, J.H.; Jung, Y.J.; Lee, C.H.; Han, D.S.; Baek, N.I. Isolation and identification of triterpenoids from the Mulberry (Morus alba) root bark. J. Appl. Biol. Chem. 2014, 57, 295-299.

12. Lee, H.J.; Lyu, D.H.; Nam, K.W.; Hong, S.S.; Kim, K.O.; Kim, K.H. Protection of prenylated flavonoids from Moricortex radicis (Moraceae) against nitric oxide-induced cell death in neuroblastoma SH-SY5Y cells. Arch. Pharm. Res. 2012, 35, 163-170. [CrossRef] [PubMed]

13. Piao, S.J.; Qiu, F.; Chen, L.X.; Pan, Y.; Dou, D.Q. New stilbene, benzofuran, and coumarin glycosides from Morus alba. Helv. Chim. Acta 2009, 92, 579-587. [CrossRef]

14. Dat, N.T.; Binh, P.T.X.; Quynh, L.T.P.; Minh, C.V.; Huong, H.T.; Lee, J.J. Cytotoxic prenylated flavonoids from Morus alba. Fitoterapia 2010, 81, 1224-1227. [CrossRef] [PubMed]

15. Geng, C.A.; Ma, Y.B.; Zhang, X.M.; Yao, S.Y.; Xue, D.Q.; Zhang, R.P.; Chen, J.J. Mulberrofuran G and isomulberrofuran $\mathrm{G}$ from Morus alba L.: Anti-hepatitis B virus activity and mass spectrometric fragmentation. J. Agric. Food Chem. 2012, 60, 8197-8202. [CrossRef] [PubMed]

16. Naik, R.; Harmalkar, D.S.; Xuezhen, X.; Jang, K.; Lee, K. Bioactive benzofuran derivatives: Moracins A-Z in medicinal chemistry. Eur. J. Med. Chem. 2015, 90, 379-393. [CrossRef] [PubMed]

17. Zhang, Z.P.; Tan, H.Y.; Wang, M.F. Tyrosinase inhibition constituents from the roots of Morus australis. Fitoterapia 2012, 83, 1008-1013. [CrossRef] [PubMed]

18. Lim, D.W.; Kim, Y.T.; Park, J.H.; Baek, N.I.; Han, D. Antidepressant-like effects of the ethyl acetate soluble fraction of the root bark of Morus alba on the immobility behavior of rats in the forced swim test. Molecules 2014, 19, 7981-7989. [CrossRef] [PubMed]

19. Jung, J.-W.; Park, J.-H.; Seo, K.-H.; Oh, E.-J.; Lee, D.-Y.; Lim, D.-W.; Han, D.; Song, M.-C.; Baek, N.-I. New hydroxy fatty acid from the root bark of Morus alba L. J. Korean Soc. Appl. Biol. Chem. 2015, 58, 541-543. [CrossRef]

20. Fukai, T.; Hano, Y.; Hirakura, K.; Nomura, T.; Uzawa, J. Structures of a novel 2-arylbenzofuran derivative and two flavones derivatives from the cultivated mulberry tree (Morus lhou Koidz.). Chem. Pharm. Bull. 1985, 33, 4288-4295. [CrossRef]

21. Hano, Y.; Nomura, T. Constituents of the Chinese crude drug "Sang-Bai-Pi" (Morus root barks). IV. Structure of Four new flavanoids, sanggenons H, I, J, and K. Heterocycles 1983, 20, 1071-1076. 
22. Jeong, S.H.; Ryu, Y.B.; Curtis-Long, M.J.; Ryu, H.W.; Baek, Y.S.; Kang, J.E.; Lee, W.S.; Park, K.H. Tyrosinase inhibitory polyphenols from roots of Morus lhou. J. Agric. Food Chem. 2009, 57, 1195-1203. [CrossRef] [PubMed]

23. Mizuno, M.; Tanaka, T.; Matsuura, N.; Linuma, M.; Cheih, C. Two flavanones from Euchresta horsfieldii. Phytochemistry 1990, 29, 2738-2740. [CrossRef]

24. Slade, D.; Ferreira, D.; Marais, P.J. Circular dichroism, a powerful tool for the assessment of absolute configuration of flavonoids. Phytochemistry 2005, 66, 2177-2215. [CrossRef] [PubMed]

Sample Availability: Samples of the compounds 1-7 are available from the authors.

(C) 2016 by the authors; licensee MDPI, Basel, Switzerland. This article is an open access article distributed under the terms and conditions of the Creative Commons Attribution (CC-BY) license (http:/ / creativecommons.org/licenses/by/4.0/). 